\title{
SPECTRAL AND TEXTURAL CHARACTERISTICS OF THE LOWLAND TROPICAL RAIN FOREST OF JAMBI, SUMATERA
}

\author{
UPIK ROSALINA WASRIN ${ }^{1}$, MUCHLISIN ARIEF ${ }^{2}$, and SETIABUDHI ${ }^{3}$ \\ 'Faculty of Forestry, Bogor Agricultural University and SEAMED BIOTROP, \\ P.O. Box 116, Bogor Indonesia; email: wasrinsy @ indo.net.id \\ ${ }^{2}$ LAPAN, Jakarta 13710, Indonesia ${ }^{3}$ SEAMEO \\ BIOTROP, P.O. Box 116, Bogor, Indonesia
}

\begin{abstract}
Analyses of Landsat TM and SPOT multispectral data were performed with a very detailed description of the vegetation cover in the field to get a relevancy and consistency of digital image classification in a semi-automatic approach. Three main vegetation types, i.e. primary forest, logged-over forest and secondary forest after clear cut were analyzed and the microclimatic parameters were also measured to describe the ecological condition of the vegetation. Spectral and textural analysis of data obtained from field measurements and spectral reflectance values of the remote sensing data are the main topic of this report as one aspect of study on the Digital Method of Detection and Monitoring on Forest Ecosystem Change Using High Resolution Satellite Data funded by the Indonesian National Research Council. This study shows that spectral reflectance values alone cannot differentiate the logged-over forest from the primary forest, but it is very sharply distinguished from the secondary forest. As for the texture analysis, it is possible to distinguish the logged-over forest from the primary forest, as shown by different values of degree of Entropy, although spatially, it is still doubtful.
\end{abstract}

Key words: Indonesia/Jambi/Tropical rain forests/lowland areas/Remote sensing/Vegetation Analysis/ Logged-over forests/Primary forests/Secondary forests.

\section{INTRODUCTION}

Analysis of remotely sensed images is commonly done by calculating the multispectral reflectance values of the objects or themes, regardless of the spectral reflectance of the neighboring pixels. This has affected the mean values and variances, which is why different objects can have the same spectral reflectance or the same objects give different spectral reflectance values. Digital data are principally dedicated to quickly evaluate and monitor the change and dynamics of the earth features such as land cover, land use, vegetation cover, development areas, etc. Especially for the vegetation cover, the change usually occurs in a slightly dynamic phenomenon and in the form of a mosaic of gaps. The conventional photo interpretation of analog satellite imageries by using the elements of interpretation such as tone or color, size, shape, texture, pattern, shadow, site, association, becomes limited to evaluate and to monitor the change, especially if the degradation occurs in a mosaic pattern.

Although this conventional interpretation contains texture and pattern, it is considered only qualitatively, and is therefore sometimes inconsistent. At present, the problems of deforestation and forest degradation are becoming a concern for many people and need to be solved before forests totally disappear. In this study, we tried to detect and indicate the significant degradation from the primary forest into 
logged-over forest, secondary forest and finally to grassland alang-alang by using spectral and textural analyses of high resolution satellite SPOT and Landsat TM data. In remote sensing analysis, the mosaic of degradation or perturbation of the vegetation cover can be translated into the form of textural pattern of pixels. However, not so many studies have been performed to analyze the textural phenomena of the vegetation status. Most studies convert the textural phenomena of the mosaic into structural information of spectral reflectance values and consider the average/mean values and variances as a major information to be used in the classification process. To be able to understand how the texture of pixels in remote sensing data significantly correlates with ground truth, a very detailed information on the vegetation characteristics obtained from field observations and measurements are provided accordingly.

\section{Study Area}

Field observations and measurements are mainly conducted inside the BIOTROP-Barito Permanent Plot, in Pasirmayang, Muarabungo, Jambi province, located between $1^{\circ} 1^{\prime} 35^{\prime \prime}$ - $1^{\circ} 5^{\prime} 55^{\prime \prime}$ latitude South and $102^{\circ} 45^{\prime} 35^{\prime}-102^{\circ} 6^{\prime} 45^{\prime \prime}$ longitude East. The observation plot for the primary forest is about 10 ha (data analyzed only from $6 \mathrm{ha}$ ), logged-over forest plot, 6 ha, secondary forest plot, one (1) ha and alang-alang plot varied according to the period of abandoned fallow (Fig. 1). The logged-over forest plot was selectively cut in 1979/1980 and 1983/1984, whereas the secondary forest was formerly devoted to transmigration area and was

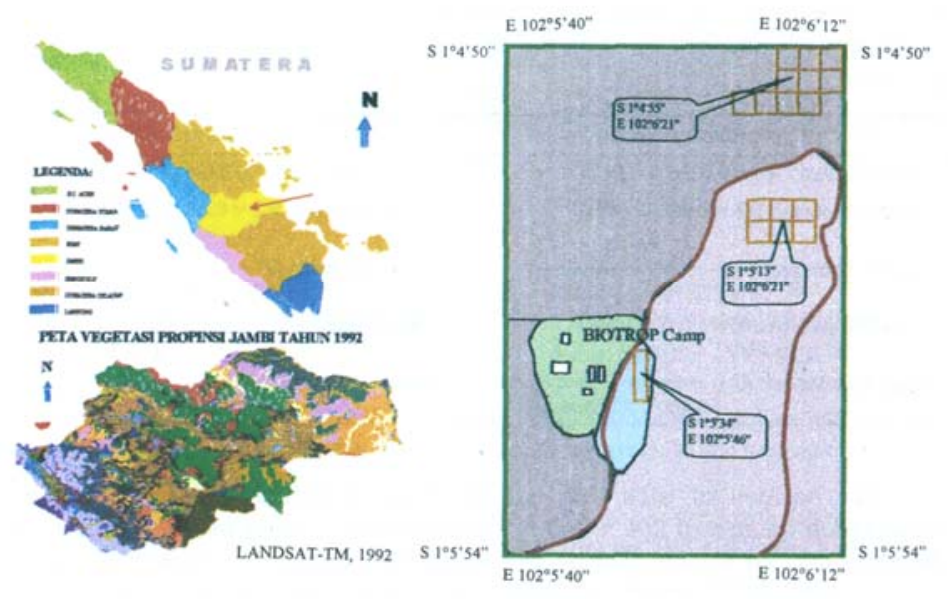

Figure 1. Location of study site at BIOTROP-Barito Permanent plot. 
totally cut (clear cut) in 1978/1979. As for grassland alang-alang, its occurrence is closely related to shifting cultivation practices, therefore, the size and distribution is varied from one place to another. All these vegetation types are located inside the 2700 ha research area near the forest plantation of Acacia mangium in Pasirmayang. The landscape of the plot is moderately undulating with an altitude between 50 $150 \mathrm{~m}$ above sea level. The forest is mainly considered as tropical lowland rain forest dominated by Dipterocarpaceae, with a total height of the emergent tree up to about $50 \mathrm{~m}$ and usually composed of multilayers. Laumonier (1992) described that the forest inside the BIOTROP observation plot consists of four dynamic phases, while Torquebiau (1988) considered the mosaic of the forest is built up by four different eco-units following the dynamic phases of reorganizing, aggrading, steady state and degrading eco-units. Many research activities have been done in the area, providing a detailed information on the vegetation community, structure, floristic and ecological factors such as soil and microclimate. It is,for this reason that the plots were chosen to support the study on spectral and textural behavior of the tropical lowland rain forest and its main derived vegetation types.

\section{METHODS}

\section{Vegetation Measurements}

The characterization of vegetation based on the parameters measured in the field is done spatially to get a synopsis of mosaic or texture. The field parameters used to highlight the textural phenomena are biomass/phytomass, leaf area index (LAI), tree density, structure (height) and crown projection. The biomass/phytomass and LAI were obtained by using the allometric equations of Ogawa et al. (1989) as follows:

\begin{tabular}{|c|c|}
\hline For Primary Forest & For Secondary Forest \\
\hline Stem biomass: $\mathrm{Ws}=0.0396\left(\mathrm{~d}^{2} \mathrm{H}\right)^{09326}$ & Stem biomass : Ws $=0.0396\left(\mathrm{~d}^{2} \mathrm{H}\right)^{09326}$ \\
\hline Branch biomass: $\mathrm{Wb}=0.00602\left(\mathrm{~d}^{2} \mathrm{H}\right)^{\prime}{ }^{\circ 27}$ & Branch biomass: $\mathrm{Wb}=0.003487\left(\mathrm{~d}^{2} \mathrm{H}\right)^{1027}$ \\
\hline Ws & Ws \\
\hline Leaves biomass: $\mathrm{WI}=\frac{}{13.75+0.025 \mathrm{Ws}}$ & Leaves biomass: $\mathrm{WI}=\frac{}{22.5+0.025 \mathrm{Ws}}$ \\
\hline Total biomass $/$ tree $=\mathrm{Ws}+\mathrm{Wb}+\mathrm{WI}$ & Total biomass $=\mathrm{Ws}+\mathrm{Wb}+\mathrm{WI}$ \\
\hline Leaf Area Index LAI $=\frac{\text { Ws }}{}$ & $\begin{array}{l}\text { Ws } \\
\text { Leaf Area Index LAI }=\end{array}$ \\
\hline $0.907+0.00205 \mathrm{Ws}$ & $2.385+0.00465 \mathrm{Ws}$ \\
\hline
\end{tabular}

The position of each tree and its crown projection are drawn inside the observation transect of $200 \times 300 \mathrm{~m}^{2}$, and measurements of total height, clear bole height at the first branch, diameter at breast height are done for each single tree with total amount of 672 trees/ha or 4032 trees/ 6 ha in each forest type (primary forest and logged-over forest). As for the secondary forest, the observation plot size is 1 ha 
with a total number of 702 trees/ha. Calculation was done for data gathered from the 6 ha primary forest and 6 ha logged-over forest following the size of a unit of spectral reflectance in remote sensing data, i.e. $20 \times 20 \mathrm{~m}$ as imitating SPOT pixel with a total unit of 150 parcels, and $30 \times 30 \mathrm{~m}$ according to Landsat TM pixel size with a total unit of 65 parcels. The calculated vegetation parameters will further be correlated with the spectral reflectance values and will be spatially analyzed to get the textural pattern of the dynamic phenomena.

\section{Spectral Analysis}

The remote sensing data used in this study are SPOT CCT data K/J = 272/353, July 1986; K/J = 278/354, July 1986 and K/J = 272/352, April 1990 and Landsat TM data path/row = 126/061, April 1994; path/row 121/060, April 1994; and aerial photographs taken in October 1992, with scale $1: 20000$ and its enlargement of 1:10 000 and 1:5000.

A significant number of Training Areas (TA) were extracted from SPOT and Landsat TM data, covering the five themes selected i.e. primary forest, logged-over forest, secondary forest, thickets and grassland alang-alang found inside the study areas. A simple statistical calculation of all TA is executed to obtain the mean value and standard deviation of each theme according to different spectral bands (SPOT, XS1-XS2-XS3; Landsat TM, TM2-TM3-TM4). To have a good figure on the representativeness of the themes, a geographical repetition is performed by using TA of other regions of West Kalimantan for Landsat TM and South Sumatera for SPOT data. A total of 179 Training Areas (TA) consisting of 122536 pixels were taken from five (5) different vegetation types such as hill and lowland primary forest, loggedover forest, secondary forest, plantation/estate, mosaic of grassland and thickets, were analysed. Those spectral reflectances were extracted from 3 scenes of SPOT and 2 scenes of Landsat TM data available and tested using Tukey student range procedure to know the difference between the mean spectral values of the vegetation types.

\section{Textural Analysis}

An almost representative sub-sample of Training Areas (TA) are taken for textural analysis. Six ha field observation plots were geographically plotted in remote sensing data of Landsat TM path/row = 126/061, April 1994 and SPOT K/J = 272/352, April 1990 (Figures 2 and 3). Spectral reflectance values are extracted from each band XS1-XS2-XS3 for SPOT and TM2-TM3-TM4 for Landsat TM and presented in the form of spectral values distribution as given in the example of TM-2 Landsat (Table 1) and SPOT XS-1 (Table 2).

Various regressions are used to get the relationships between these spectral reflectances with the field parameters especially biomass and LAI which are taken as exactly as possible from the same unit/pixel. While a general feature of the vegetation mosaic is obtained from aerial photo's interpretation on scale $1: 5769$ 
Spectral and textural characteristics - Upik R. Wasrin et al.

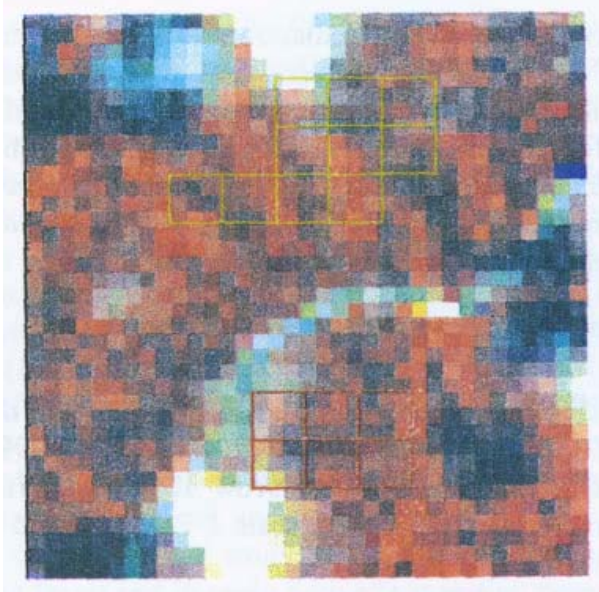

Figure 2. Position of primary forest plot (yellow) and logged-over forest plot (red) on Landsat TM false color composite, with an enlargement of 9 times.

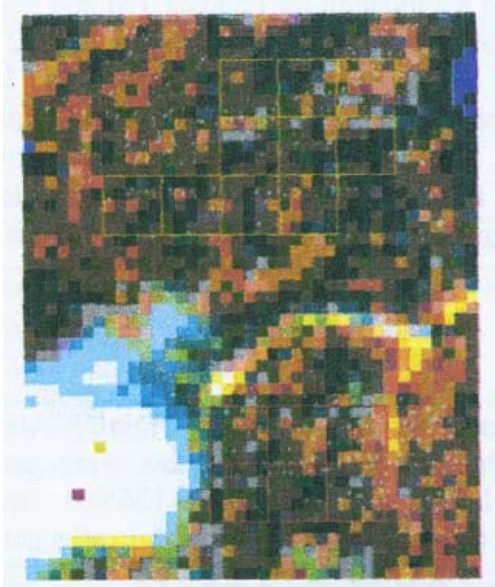

Figure 3. Position of primary forest plot (yellow) and logged-over forest plot (red) on SPOT false color composite, with an enlargement of 7 times. 
BIOTROPIANo. 13, 1999

Table 1. Spectral reflectance values of Band TM2 Landsat from primary forest

\begin{tabular}{|l|l|l|l|l|l|l|}
\hline 61 & 58 & 29 & 13 & 13 & 11 & 11 \\
\hline 31 & 28 & 19 & 13 & 11 & 11 & 14 \\
\hline 15 & 13 & 16 & 12 & 11 & 11 & 11 \\
\hline 13 & 13 & 12 & 12 & 10 & 10 & 12 \\
\hline 13 & 12 & 13 & 13 & 10 & 11 & 10 \\
\hline 13 & 12 & 12 & 12 & 12 & 13 & 12 \\
\hline 12 & 11 & 13 & 12 & 12 & 11 & 11 \\
\hline 13 & 11 & 10 & 13 & 11 & 12 & 11 \\
\hline 11 & 12 & 12 & 12 & 11 & 12 & 12 \\
\hline 12 & 10 & 11 & 13 & 12 & 13 & 12 \\
\hline
\end{tabular}

Table 2. Spectral reflectance values of Band XS1 SPOT from primary forest

\begin{tabular}{|l|l|l|l|l|l|l|l|l|l|}
\hline 25 & 24 & 25 & 24 & 24 & 23 & 23 & 23 & 25 & 26 \\
\hline 25 & 25 & 25 & 24 & 25 & 25 & 24 & 24 & 27 & 25 \\
\hline 25 & 24 & 24 & 24 & 25 & 26 & 24 & 25 & 26 & 25 \\
\hline 25 & 23 & 25 & 25 & 25 & 24 & 24 & 25 & 24 & 26 \\
\hline 25 & 25 & 25 & 27 & 25 & 25 & 24 & 24 & 25 & 25 \\
\hline 25 & 26 & 28 & 26 & 25 & 25 & 26 & 23 & 24 & 26 \\
\hline 27 & 26 & 28 & 25 & 25 & 25 & 25 & 24 & 25 & 25 \\
\hline 24 & 25 & 26 & 25 & 25 & 24 & 23 & 22 & 24 & 24 \\
\hline 24 & 24 & 25 & 24 & 25 & 25 & 25 & 24 & 23 & 24 \\
\hline 24 & 24 & 24 & 23 & 24 & 24 & 23 & 25 & 25 & 26 \\
\hline 23 & 25 & 25 & 24 & 23 & 24 & 25 & 24 & 25 & 24 \\
\hline 23 & 23 & 25 & 24 & 24 & 24 & 25 & 23 & 24 & 25 \\
\hline 23 & 24 & 24 & 26 & 25 & 25 & 24 & 24 & 24 & 23 \\
\hline 25 & 24 & 24 & 24 & 24 & 24 & 23 & 24 & 25 & 24 \\
\hline 24 & 23 & 24 & 25 & 24 & 24 & 24 & 25 & 27 & 24 \\
\hline
\end{tabular}

with 95\% accuracy for the primary forest and 96\% accuracy for the logged-over forest. In the aerial photos, the vegetation covers were divided into 4 layers i.e. the emergent frees with height from 45 - 55 (60) m, the canopy layer from 30 - $40 \mathrm{~m}$, the under layer (sub-canopy) layer from 15 - $25 \mathrm{~m}$ and the ground cover/gaps from 2 - $10 \mathrm{~m}$ above the forest floor.

To get the indication of textural pattern, a simple statistical approach is used to calculate the level of Entropy $\left(\mathrm{H}^{\prime}\right)$ by using the equation as follows:

$$
H^{\prime}=3.3219\left(\operatorname{logio}_{N}-1 / N \sum_{I=1} n \operatorname{Iog}_{10} n i\right)
$$


where : $\quad \mathrm{H}^{\prime}=$ Entropy level

$\mathrm{N}=$ total number of pixels/parcels

$\mathrm{Ni}=$ number of pixels/parcels of class $1=1,2,3, \ldots \mathrm{m}$

Although this index is not an absolute value, it still can give a general idea on the differences between one texture of a certain object compared to the texture of the other objects. To make the value of Entropy level $\left(\mathrm{H}^{\prime}\right)$ more significant, it has to be complemented with a spatial arrangement of the pixel's values.

\section{RESULTS}

\section{Vegetation Characteristics}

The quantitative description of the forest according to diameter and height distributions of the trees gives an indication that the two forest types under study are considered to have a normal distribution, following $\mathrm{J}$ inverse for diameter distribution and cloche-like form for height distribution. Therefore, there is no significant difference between these statistical and quantitative approaches.

Figure 4 gives a general view of the primary forest and logged-over forest from aerial photos at scale $1: 20000$. These figures show a very different synopsis of the two forest types, where the mosaic of primary forest appears to be more rigorous than those of logged-over forest. The primary forest is still densely covered by the canopy layer and the emergent trees, while in the logged-over forest the canopy layer and the emergent trees are randomly scattered throughout the observation plot (6 ha). From aerial photographs, it is certainly possible to distinguish between the

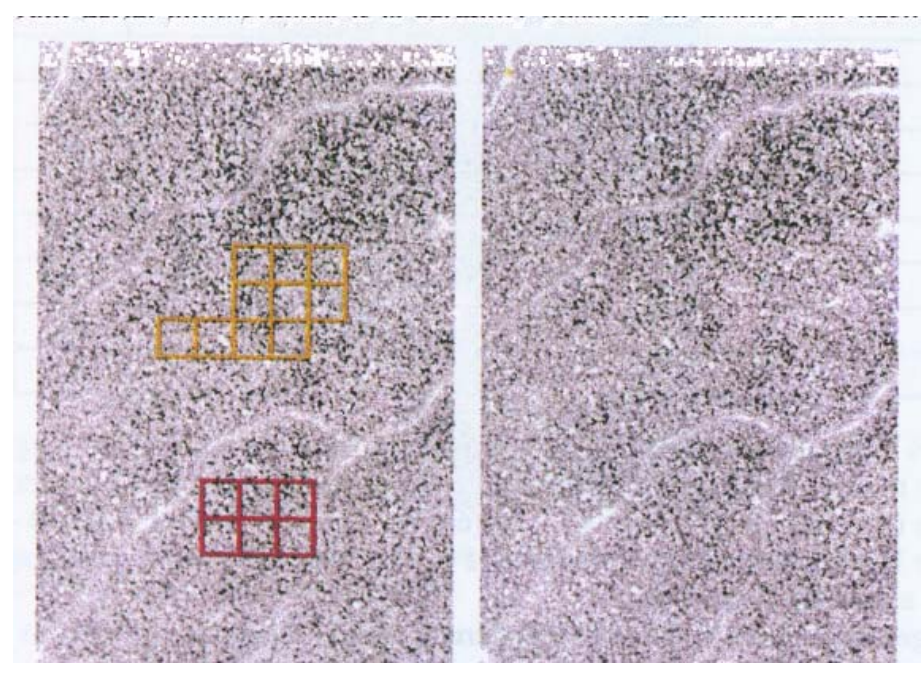

Figure 4. General view of primary forest (yellow) and logged-over forest (red) on stereo-pair of aerial photos (scale $\pm 1: 20000$ ). 
primary forest and the logged-over forest by looking at the ratio of percentage of the vegetation layers and other parameters such as tree density, volume and tree distribution.

A similar procedure is done in the analysis of field parameters such as LAI (Figures 5,6, 7 \& 8) and biomass (Figures 9, 10, 11 \& 12) of the primary forest and logged-over forest. To enhance the pattern of textural phenomena, the data are regrouped into 8 classes according to pixel sizes of Landsat (30x30 m) and SPOT (20x20 m) for both vegetation types, primary forest and logged-over forest.

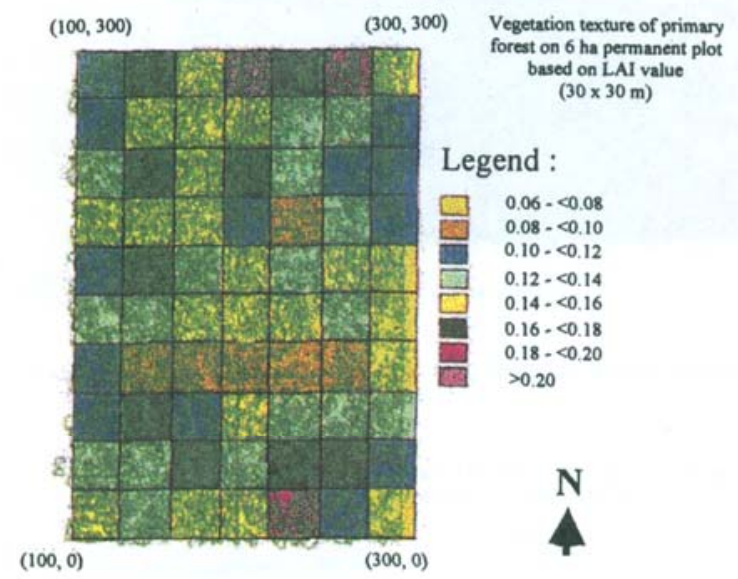

Figure 5. The vegetation texture of the primary forest plot following the Landsat pixel size.

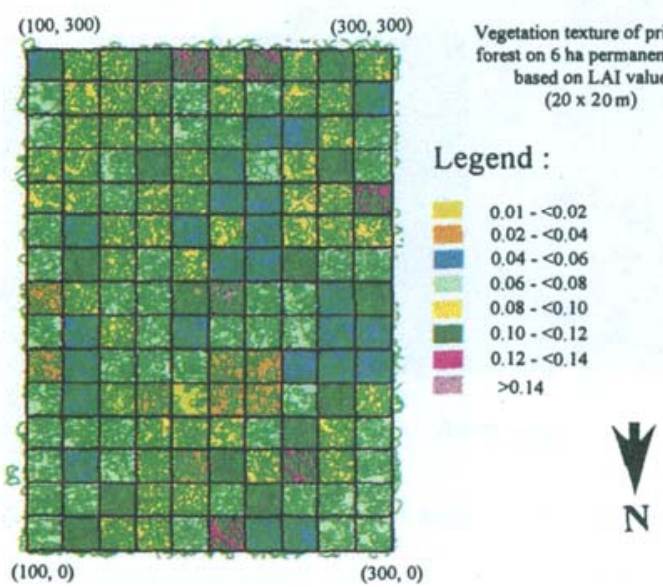

Figure 6. The vegetation texture of the primary forest plot following the SPOT pixel size. 
Spectral and textural characteristics - Upik R. Wasrin et al.

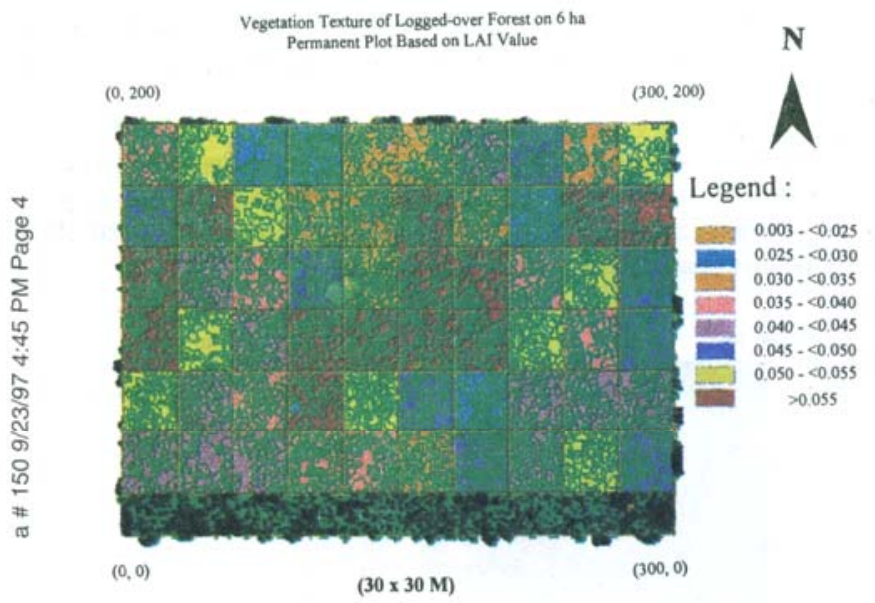

Figure 7. The vegetation tecxture of the logged-over forest plot following the Landsat-TM pixel size.

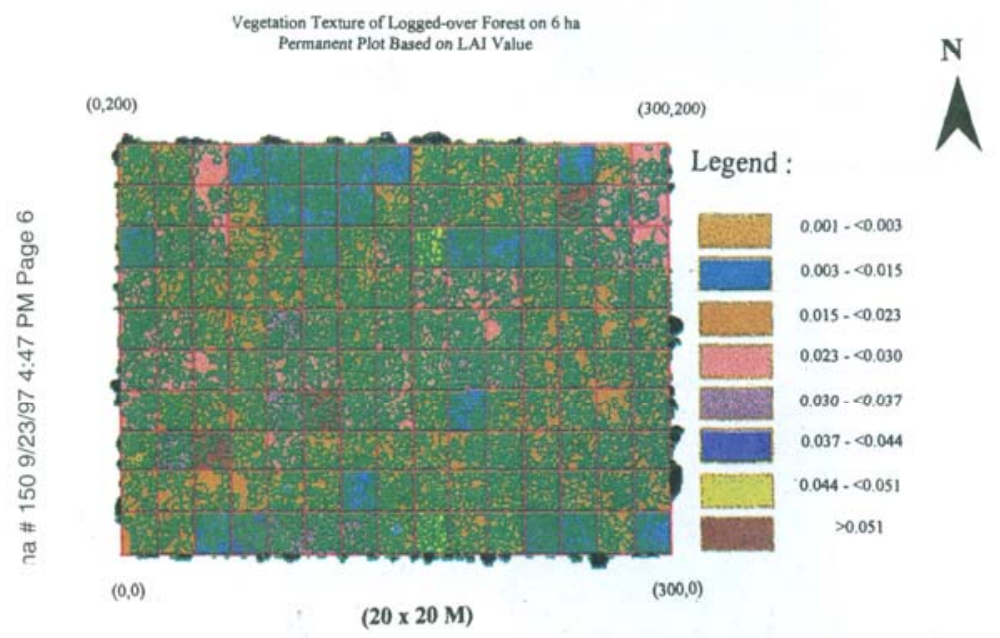

Figure 8. The vegetation texture of the logged-over forest plot based on LAI value following the SPOT pixel size. 
BIOTROPIA No. 13, 1999

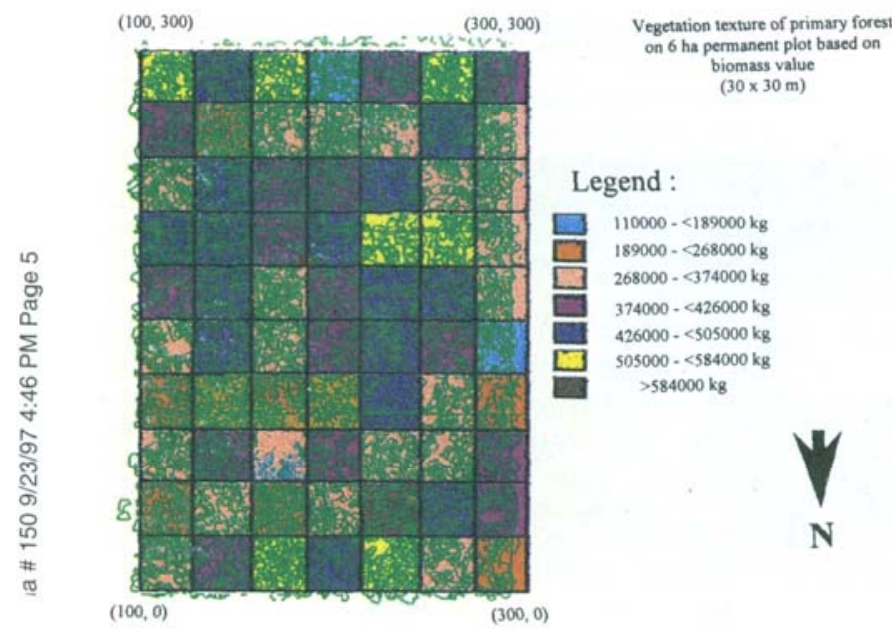

Figure 9. The vegetation texture of the primary forest plot based on biomass following the Landsat-TM pixel size.

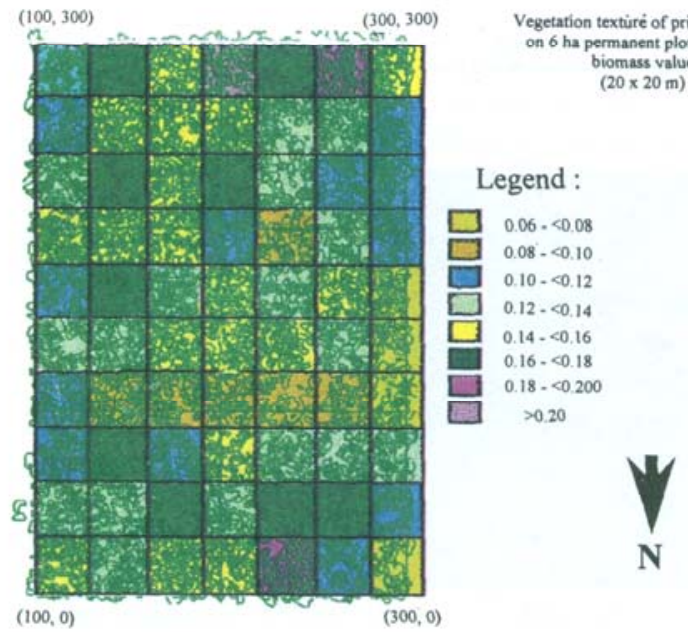

Figure 10. The vegetation texture of the primary forest plot based on biomass following the SPOT pixel size. 
Spectral and textural characteristics - Upik R. Wasrin et al.

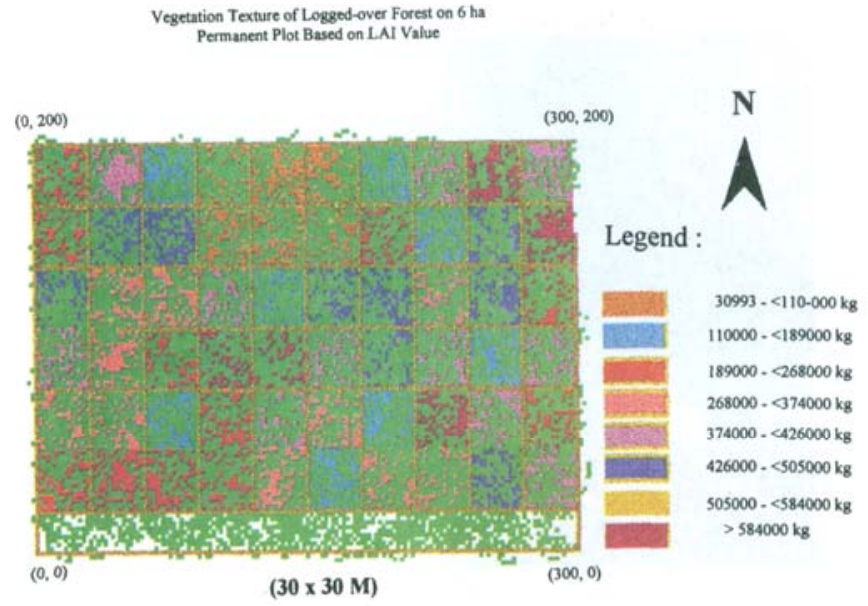

Figure 11. The vegetation texture of the logged-over forest plot based on biomass following the LandsatTM pixel size.

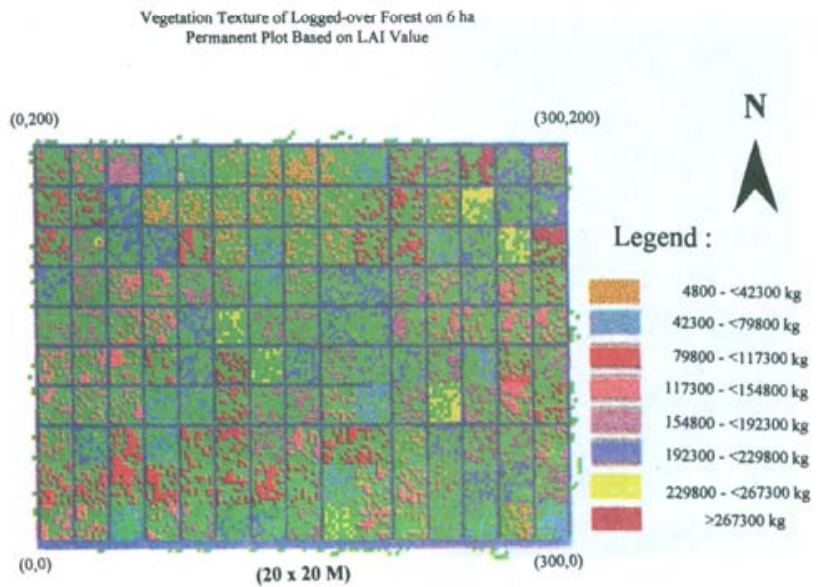

Figure 12. The vegetation texture of the logged-over forest plot based on biomass following the SPOT pixel size. 


\section{Spectral Analysis}

The mean spectral values obtained from 3 different sites of SPOT images and 2 sites on Landsat TM images are still varied, especially for thickets and alang-alang on SPOT and almost for every vegetation type on Landsat TM image (Table 3).

Although the Landsat TM resolution is nearly as high as SPOT resolution, a relatively different mean and standard deviation or variance are recorded from the same vegetation types. It can be explained by the fact that radiometric resolution of Landsat TM is not at the optimum range of radiation wavelength particularly for the vegetation response.

To have a proper analysis on the mean spectral values of various vegetation types according to spectral band and images used, a procedure of Tukey student range is applied to give a confidential range as given in Tables 4 and 5. The Tstudent range is very high in all spectral band of SPOT and Landsat TM, indicating that statistically the mean spectral values are not significantly different from one to another.

Table 5 also shows no significant difference among the mean spectral values, except between primary forest and thickets and between logged-over forest and thickets, in spectral band of Landsat TM-3.

Based on the spectral reflectance alone, it is hard to distinguish the difference between the primary forest and the logged-over forest. However, the physiognomy has a great contribution in differentiating the primary forest with the other degraded types such as secondary forest, thickets and alang-alang, and plantation or estate, both in SPOT and Landsat TM data. The Tukey student test for analyzing the mean spectral values supports this result, where primary forest and logged-over forest almost have no difference in spectral reflectance values. A quite important variability of spectral reflectance values (mean and variance) obtained in Landsat TM data is probably due to inhomogeneity and different geographical location of the training areas extracted from the images (Jambi and West Kalimantan). Figures 13 and 14 show the distribution of the spectral reflectance from different training areas (TA) taken from two different geographical location using Landsat TM and SPOT data. No clear pattern of spectral distribution classes is shown in these graphs. Therefore, this spectral analysis should eventually be complemented with textural analysis, in order to distinguish the pattern of the vegetation mosaic according to dynamic phenomena.

\section{Correlation between Spectral Reflectance and Vegetation Parameters}

Tests of correlations between spectral reflectance values and vegetation parameters such as LAI and biomass are performed to know the relevancy of data gathered from vegetation measurement in the field with respect to the spectral relectance response.

From Tables 6 \& 7, it is obvious that all parameters tested are highly correlated, especially between bands TM3 and TM4 with biomass for the primary forest as well 
Spectral and textural characteristics - Upik R. Wasrin et al.

Table 3. Spectral reflectance values extracted I om SPOT and Landsat TM images

\begin{tabular}{|c|c|c|c|c|c|c|c|c|c|}
\hline \multirow[t]{2}{*}{ No. } & SPOT Data & \multicolumn{4}{|c|}{ SPOT XS-1 } & \multicolumn{2}{|c|}{ SPOT XS-2 } & \multicolumn{2}{|c|}{ SPOT XS-3 } \\
\hline & $\begin{array}{l}\text { Vegetation } \\
\text { types }\end{array}$ & $\begin{array}{l}\text { No. of } \\
\text { Pixels }\end{array}$ & TA & Mean & Sd & Mean & Sd & Mean & $\mathrm{Sd}$ \\
\hline \multirow[t]{4}{*}{1} & Lowland Primary & 1413 & 1. & 17.00 & 0.70 & 45.00 & 1.10 & 64.00 & 3.90 \\
\hline & forest & 15284 & 2. & 16.68 & 0.78 & 31.42 & 1.04 & 74.40 & 6.08 \\
\hline & & & 3. & - & - & - & - & - & - \\
\hline & & Average & & 16.84 & 0.74 & 38.21 & 1.07 & 69.20 & 4.99 \\
\hline \multirow[t]{4}{*}{2} & Logged-over & 6245 & 1. & 22.50 & 0.80 & 44.10 & 1.24 & 75.40 & 5.40 \\
\hline & forest & 6726 & 2. & 18.20 & 1.54 & 32.80 & 1.28 & 68.50 & 6.01 \\
\hline & & 3252 & 3. & 19.00 & 0.70 & 33.00 & 0.70 & 72.00 & 2.80 \\
\hline & & Average & & 19.90 & 1.01 & 36.63 & 1.07 & 71.97 & 4.74 \\
\hline \multirow[t]{4}{*}{3} & Secondary forest & 1960 & 1. & 24.00 & 0.90 & 46.00 & 1.00 & 84.00 & 4.20 \\
\hline & & 4801 & 2. & 18.00 & 0.67 & 32.60 & 0.85 & 9.6075 .00 & 4.17 \\
\hline & & 2041 & 3. & 20.00 & 0.80 & 36.00 & 0.90 & & 2.60 \\
\hline & & Average & & 20.67 & 0.79 & 38.20 & 0.92 & 79.53 & 3.66 \\
\hline \multirow[t]{4}{*}{4} & Thickets \& alang- & 1004 & 1. & 25.00 & 0.70 & 48.00 & 0.90 & 98.00 & 2.80 \\
\hline & alang & 22581066 & 2. & 18.20 & 0.76 & 29.20 & 0.28 & 95.60 & 4.70 \\
\hline & & & 3. & 24.00 & 1.00 & 39.00 & 1.30 & 74.00 & 4.10 \\
\hline & & Average & & 22.40 & 0.82 & 38.73 & 0.83 & 89.20 & 3.87 \\
\hline \multirow[t]{4}{*}{5} & Plantation/ Estate & 714 & 1. & - & - & - & - & - & - \\
\hline & & 2730 & 2. & 18.20 & 0.75 & 31.80 & 0.90 & 82.50 & 2.48 \\
\hline & & & 3. & 18.00 & 0.80 & 32.00 & 1.00 & 77.00 & 2.90 \\
\hline & $"$ & Average & & 18.10 & 0.78 & 31.90 & 0.95 & 79.75 & 2.69 \\
\hline \multirow[t]{2}{*}{ No. } & Landsat TM & & TA & TM-1 & & TM-2 & & TM-3 & \\
\hline & Vegetation types & No. of Pixels & & Mean & Sd & Mean & Sd & Mean & Sd \\
\hline \multirow[t]{3}{*}{1} & Low primary & 4994 & 1. & 23.30 & 0.91 & 23.06 & 1.08 & 67.20 & 7.09 \\
\hline & forest & 2598 & 2 & 21.60 & 0.93 & 17.50 & 1.06 & 67.60 & 7.01 \\
\hline & & Average & & 22.45 & 0.92 & 20.28 & 1.07 & 67.40 & 7.05 \\
\hline \multirow[t]{3}{*}{2} & Logged-over & 3905 & 1. & 20.40 & 1.26 & 20.40 & 1.54 & 60.30 & 6.96 \\
\hline & forest & 6763 & 2 & 21.95 & 0.93 & 17.88 & 1.18 & 65.28 & 6.41 \\
\hline & & Average & & 21.18 & 1.10 & 19.14 & 1.36 & 62.79 & 6.69 \\
\hline \multirow[t]{3}{*}{3} & Secondary fore'st & 3391 & 1. & 24.70 & 0.81 & 24.60 & 1.08 & 76.70 & 4.00 \\
\hline & & 1046 & 2. & 23.60 & 0.88 & 19.10 & 0.93 & 79.90 & 5.75 \\
\hline & & Average & & 24.15 & 0.85 & 21.85 & 1.01 & 78.30 & 4.88 \\
\hline \multirow[t]{3}{*}{4} & Thickets \& alang- & 1955 & -1. & 23.73 & 1.34 & 26.50 & 1.44 & 90.50 & 6.93 \\
\hline & alang & 1414 & 2 & 27.30 & 1.31 & 21.70 & 1.20 & 99.40 & 8.15 \\
\hline & & Average & & 25.52 & 1.33 & 24.10 & 1.32 & 94.95 & 7.54 \\
\hline \multirow[t]{3}{*}{5} & Plantation/ Estate & 2128 & 1.2 . & 23.80 & 0.84 & 23.90 & 1.05 & 77.50 & 3.88 \\
\hline & & 2760 & & 26.33 & 0.89 & 22.84 & 1.00 & 89.84 & 4.90 \\
\hline & & Average & & 25.07 & 0.87 & 23.37 & 1.03 & 83.67 & 4.39 \\
\hline
\end{tabular}


Spectral and textural characteristics - Upik R. Wasrin et al.

Table 4. Tukey student range (w) values to compare mean spectral value of each spectral band

\begin{tabular}{cccc}
\multicolumn{2}{c}{ SPOT } & \multicolumn{2}{c}{ Landsat TM } \\
\hline XS-1 & 18.28 & TM-1 & 5.27 \\
XS-2 & 38.92 & TM-2 & 9.96 \\
XS-3 & 75.53 & TM-3 & 16.98 \\
\hline
\end{tabular}

Table 5. Tukey student range for mean spectral values with confidential level 95\%

\begin{tabular}{|c|c|c|c|c|c|}
\hline Images & Frim. tọ. & Logegd. for. & Second, for. & thickéts. & pleytarion \\
\hline SPOT XS-I & 16.84 & 19.90 & 20.67 & 22.40 & 18.10 \\
\hline SPOT KS-2 & $\begin{array}{r}x-\ldots . . . .1 \\
38.21\end{array}$ & $\begin{array}{c}-x \\
35.63\end{array}$ & 39.20 & 3 & $\begin{array}{l}-x \\
31.90\end{array}$ \\
\hline SPOT X5-3 & $\begin{array}{r}x \\
69.20\end{array}$ & 71.97 & 79.53 & 89.20 & - 79.75 \\
\hline Latudsat TM-i & 22.45 & $\frac{-1.18}{21.18}$ & 24.15 & 25.52 & $=x$ \\
\hline L.tundsat TM-2 & $\begin{array}{c}x \cdots \cdot \ldots \\
20,29 \\
x \ldots \ldots \ldots\end{array}$ & 19.14 & $\begin{array}{l}21.65 \\
21-1 .\end{array}$ & $\begin{array}{l}-x \cdot \cdots \cdots \\
24.10\end{array}$ & $\begin{array}{c}x \\
23.37\end{array}$ \\
\hline Landsat TM-3 & 67.40 & 62.79 & 79.30 & 94.95 & 83,67 \\
\hline & $x$ & $\ldots$ & r., & 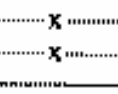 & $\begin{array}{l}x \\
x \\
x\end{array}$ \\
\hline
\end{tabular}

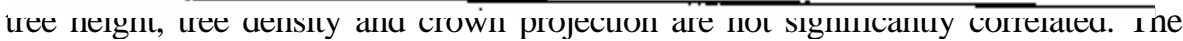
same analysis for the correlation between the spectral reflectance of SPOT data with the vegetation parameters showed similar results where biomass and LAI have a good correlation with SPOT spectral values, while no significant correlationn was found between spectral reflectance and tree height, tree density and crown projection (Tables 8 and 9).

However, Franklin and McDermid (1993) found that there is a significant correlation between green band (XS-2) with mean diameter at breast height, height, age and volume of the Pinus forest stand, while with the infrared band (XS-3) these stand parameters showed a poor correlation. As for Landsat TM data, Trotter et al. (1997) examined the relationship between wood volume of the coniferous stand and Landsat TM data and gave the conclusion that Landsat TM only provides an acceptable information for estimating the wood volume in plantation forest of a minimum 40 ha areas. While Cohen and Spies (1992) obtained a correlation coefficient between 0.45 and 0.88 for the relation between HRV panchromatic texture with stand attributes such as tree bole diameter, tree height, tree density, age and a structural complexity index; while for TM wetness the coefficient correlation is between 0.51 and 0.90 . He also concluded that the lowest correlation is for tree 
BIOTROPIA No. 13, 1999
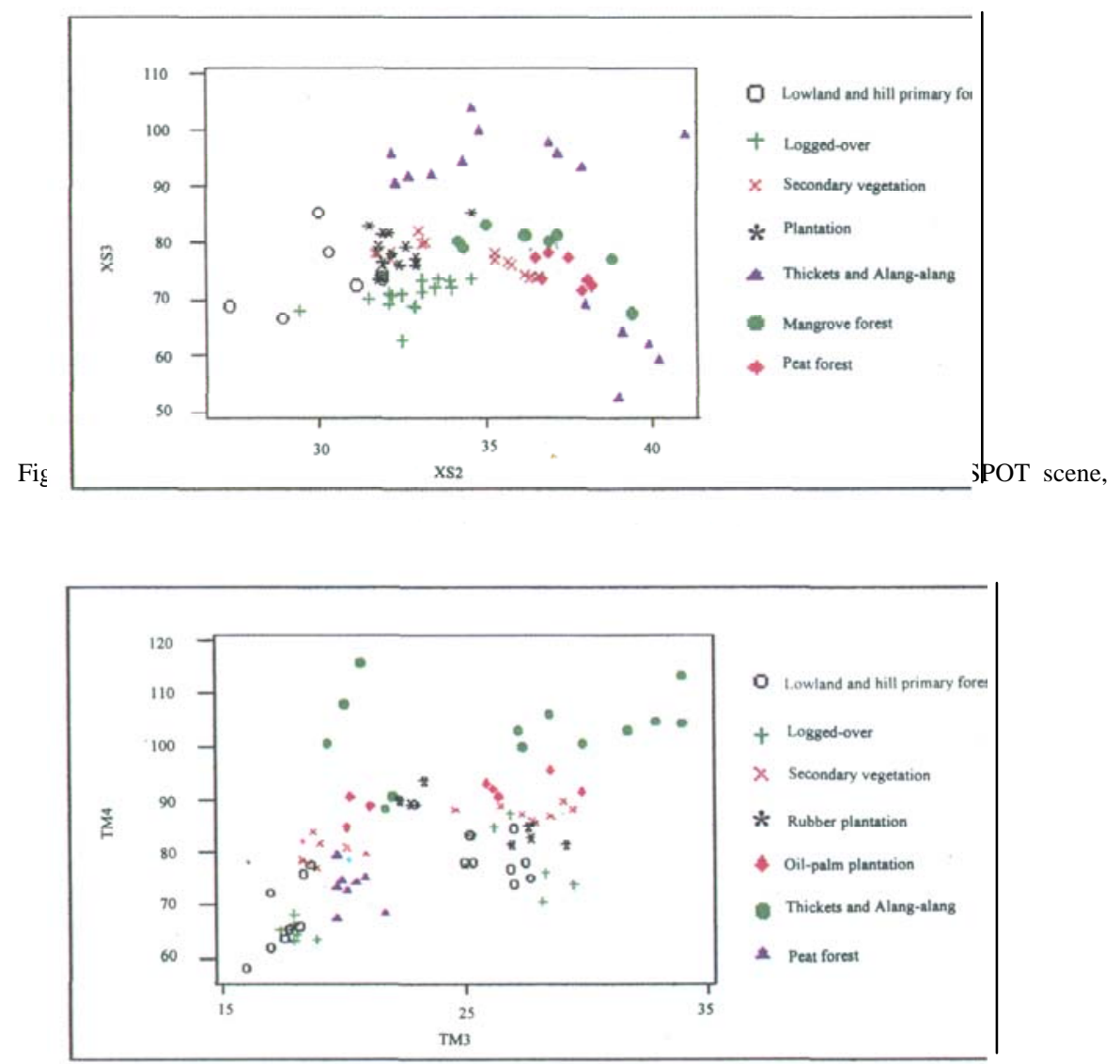

Figure 13. Distribution of spectral reflectance. Values of the treaining areas obtained from Landsat-TM scene, path/row : 126/061 and 121/060. 
Table 6. Correlation of Landsat TM spectral reflectance with vegetation parameters of the Primary forest

\begin{tabular}{|c|c|c|c|c|}
\hline No. & Corr. between & Regression formula & $\begin{array}{l}\text { Coef. of } \\
\text { regression }\end{array}$ & Regression formula \\
\hline 1. & TM3 - Biomass & $\begin{array}{l}\text { - Logarithm } \\
\text { - Polynomial } \\
\text { - Linear } \\
\text { - Power } \\
\text { - Exponential }\end{array}$ & $\begin{array}{l}0.9988 \\
1.0000 \\
1.0000 \\
0.9592 \\
0.9446\end{array}$ & $\begin{array}{l}Y=368.63 \operatorname{Ln}(x)-1167.7 \\
Y=5.10^{-13} x^{2}+13 x-304.5 \\
Y=13 x-304.5 \\
Y=2.10^{-8} x^{6.5597} \\
Y=0.084 e^{0.2294 x}\end{array}$ \\
\hline 2. & TM3 - LAI & $\begin{array}{l}\text { - Logarithm } \\
\text { - Polynomial } \\
\text { - Linear } \\
\text { - Power } \\
\text { - Exponential }\end{array}$ & $\begin{array}{l}0.9820 \\
0.9935 \\
0.9687 \\
0.9382 \\
0.9103\end{array}$ & $\begin{array}{l}Y=0.5092 \operatorname{Ln}(x)-1.5661 \\
Y=-0.0009 x^{2}+0.0682 x-1.1049 \\
Y=0.0171 x-0.3496 \\
Y=7.10^{-7} x^{3.6434} \\
Y=0.0041 \mathrm{e}\end{array}$ \\
\hline 3. & TM4 - Biomass & $\begin{array}{l}\text { - Logarithm } \\
\text { - Polynomial } \\
\text { - Linear } \\
\text { - Power } \\
\text { - Exponential }\end{array}$ & $\begin{array}{l}0.9918 \\
1.0000 \\
1.0000 \\
0.9779 \\
0.9446\end{array}$ & $\begin{array}{l}Y=143.26 \operatorname{Ln}(x)-594.26 \\
Y=-9.10^{16} x^{2}+1.4444 x-82.056 \\
Y=1.4444 x-82.056 \\
Y=0.0004 x^{2.583} \\
Y=4.2575 \mathrm{e}\end{array}$ \\
\hline 4. & TM4 - LAI & $\begin{array}{l}\text { - Logarithm } \\
\text { - Polynomial } \\
\text { - Linear } \\
\text { - Power } \\
\text { - Exponential }\end{array}$ & $\begin{array}{l}0.9918 \\
1.0000 \\
1.0000 \\
0.9957 \\
0.9759\end{array}$ & $\begin{array}{l}Y=0.2204 \operatorname{Ln}(\mathrm{x})-0.8758 \\
\mathrm{Y}=3.10^{-18} \mathrm{x}^{2}+0.0022 \mathrm{x}-0.0878 \\
\mathrm{Y}=0.0022 \mathrm{x}-0.0878 \\
\mathrm{Y}=5.10^{-5} \mathrm{x}^{1.7131} \\
\mathrm{Y}=0.023 \mathrm{e}^{0.017 \mathrm{x}}\end{array}$ \\
\hline
\end{tabular}

Table 7. Correlation of Landsat TM spectral reflectance with vegetation parameters of the Logged forest

\begin{tabular}{|c|c|c|c|c|}
\hline No. & Corr. between & Regression fornula & $\begin{array}{l}\text { Coef. of } \\
\text { regression }\end{array}$ & Regression formula \\
\hline 1. & TM3 - Biomass & $\begin{array}{l}\text { - Logarithm } \\
\text { - Polynomial } \\
\text { - Linear } \\
\text { - Power } \\
\text { - Exponential }\end{array}$ & $\begin{array}{l}0.9920 \\
1.0000 \\
1.0000 \\
0.9536 \\
0.9112\end{array}$ & $\begin{array}{l}Y=879.65 \operatorname{Ln}(x)-2750.2 \\
Y=-2.10^{-13} x^{2}+26.333 x+562 \\
Y=26.333 x-562 \\
Y=0.0027 x^{3.2873} \\
Y=10.48 e^{0.0958 x}\end{array}$ \\
\hline 2. & TM3 - LAI & $\begin{array}{l}\text { - Logarithm } \\
\text { - Polynomial } \\
\text { - Linear } \\
\text { - Power } \\
\text { - Exponential }\end{array}$ & $\begin{array}{l}0.9804 \\
0.9931 \\
0.9619 \\
0.8938 \\
0.8488\end{array}$ & $\begin{array}{l}Y=0.0641 \operatorname{Ln}(x)-0.1869 \\
Y=-6.10^{-05} x^{2}+0.0057 x-0.0879 \\
Y=0.002 x^{-0.0287} \\
Y=0.00002 x^{2.0983} \\
Y=0.0042 e^{0.0634 x}\end{array}$ \\
\hline 3. & TM4 - Biomass & $\begin{array}{l}\text { - Logarithm } \\
\text { - Polynomial } \\
\text { - Linear } \\
\text { - Power } \\
\text { - Exponential }\end{array}$ & $\begin{array}{l}0.9976 \\
1.0000 \\
1.0000 \\
0.9357 \\
0.9112\end{array}$ & $\begin{array}{l}Y=-1613.6 \operatorname{Ln}(x)-6763.9 \\
Y=-2.10^{-13} x^{2}+19.75 x-1282.9 \\
Y=-19.75 x-1282.9 \\
Y=10^{-9} x^{5.9545} \\
Y=0.7608 e^{0.0719 x}\end{array}$ \\
\hline 4. & TM4 - LAI & $\begin{array}{l}\text { - Logarithm } \\
\text { - Polynomial } \\
\text { - Linear } \\
\text { - Power } \\
\text { - Exponential }\end{array}$ & $\begin{array}{l}0.9730 \\
0.9831 \\
0.9619 \\
0.8736 \\
0.8488\end{array}$ & $\begin{array}{l}Y=0.1188 \operatorname{Ln}(x)-0.4846 \\
Y=-3.10^{-05} x^{2}+0.0066 x-0.2856 \\
Y=0.0015 x-0.0827 \\
Y=2.10^{-9} x^{3.8579} \\
Y=0.0007 e^{0.0476 x}\end{array}$ \\
\hline
\end{tabular}


BIOTROPIA No. 13, 1999

Table 8. Correlation of SPOT spectral reflectance with vegetation parameters of the logged-over forest

\begin{tabular}{|c|c|c|c|c|}
\hline No. & Corr. between & Regression formula & $\begin{array}{l}\text { Coef. of } \\
\text { regression }\end{array}$ & Regression formula \\
\hline \multirow[t]{5}{*}{1.} & XSI - LAI & - Logarithm & 0.8534 & $\mathrm{Y}=-0.8992 \operatorname{Ln}(\mathrm{x})+28.027$ \\
\hline & & - Polynomial & 0.8456 & $\mathrm{Y}=0.0001 \mathrm{x}^{2}-0.0343 \mathrm{x}+26.227$ \\
\hline & & - Linear & 0.8114 & $\mathrm{Y}=-0.0191 \mathrm{x}+25.839$ \\
\hline & & - Power & 0.8423 & $\mathrm{Y}=28.214 \mathrm{x}^{-0.0362}$ \\
\hline & & - Exponential & 0.8196 & $\mathrm{Y}=25.855 \mathrm{e}^{-0.0008 x}$ \\
\hline \multirow[t]{5}{*}{2.} & XS1 - Biomass & - Logarithm & 0.7897 & $\mathrm{Y}=6.2571 \operatorname{Ln}(\mathrm{x})-11.733$ \\
\hline & & - Polynomial & 0.9649 & $Y=-6 E-05 x^{2}+0.1593 x+1.9251$ \\
\hline & & - Linear & 0.9647 & $\mathrm{Y}=0.1504 \mathrm{x}+2.1503$ \\
\hline & & - Power & 0.9073 & $\mathrm{Y}=0.6909 \mathrm{x}^{0.6923}$ \\
\hline & & - Exponential & 0.8304 & $\mathrm{Y}=3.801 \mathrm{e}^{0.0144 \mathrm{x}}$ \\
\hline \multirow[t]{5}{*}{3.} & $\mathrm{XS} 3$ - LAI & - Logarithm & 0.7879 & $\mathrm{Y}=4.1374 \operatorname{Ln}(\mathrm{x})+59.485$ \\
\hline & & - Polynomial & 0.9542 & $Y=0.0002 x^{2}+0.0735 x+69.354$ \\
\hline & & - Linear & 0.9501 & $Y=0.0988 x+68.714$ \\
\hline & & - Power & 0.8170 & $\mathrm{Y}=60.885 \mathrm{x}^{0.0551}$ \\
\hline & & - Exponential & 0.9536 & $\mathrm{Y}=68.963 \mathrm{e}^{0.0013 \mathrm{x}}$ \\
\hline \multirow[t]{5}{*}{4.} & XS3 - Biomass & - Logarithm & 0.7897 & $Y=20.857 \operatorname{Ln}(x)-39.109$ \\
\hline & & - Polynomial & 0.9649 & $Y=-0.0002 x^{2}+0.5309 x+6.417$ \\
\hline & & - Linear & 0.9647 & $Y=0.5013 x+7.1677$ \\
\hline & & - Power & 0.9073 & $\mathrm{Y}=2.3031 \mathrm{x}^{0.6923}$ \\
\hline & & - Exponential & $0 . .8304$ & $\mathrm{Y}=12.67 \mathrm{e}^{0.0144 \mathrm{x}}$ \\
\hline
\end{tabular}

Table 9. Correlation of SPOT spectral reflectance with vegetation parameters of the primary forest

\begin{tabular}{|c|c|c|c|c|}
\hline No. & Corr. between & Regression formula & $\begin{array}{l}\text { Coef. of } \\
\text { regression }\end{array}$ & Regression formula \\
\hline \multirow[t]{5}{*}{1.} & XS1 - LAI & - Logarithm & 0.6634 & $\mathrm{Y}=0.869 \operatorname{Ln}(\mathrm{x})+21.022$ \\
\hline & & - Polynomial & 0.8273 & $\mathrm{Y}=6 \mathrm{E}-05 \mathrm{x}^{2}+0.0117 \mathrm{x}+23.178$ \\
\hline & - & - Linear & 0.8169 & $\mathrm{Y}=0.021 \mathrm{x}+22.943$ \\
\hline & & - Power & 0.6871 & $Y=21.222 x+0.0357$ \\
\hline & & - Exponential & 0.8265 & $Y=22.982 e^{0.0009 x}$ \\
\hline \multirow[t]{5}{*}{2.} & XS1 - Biomass & - Logarithm & 0.6970 & $\mathrm{Y}=6.8089 \operatorname{Ln}(\mathrm{x})-13.293$ \\
\hline & & - Polynomial & 0.8701 & $\mathrm{Y}=0.0002 \mathrm{x}^{2}+0.1314 \mathrm{x}+2.5547$ \\
\hline & & - Linear & 0.8677 & $Y=0.1652 x+1.6975$ \\
\hline & & - Power & 0.8758 & $\mathrm{Y}=0.5178 \mathrm{x}^{0.7662}$ \\
\hline & & - Exponential & 0.7638 & $\mathrm{Y}=3.5162 \mathrm{e}^{0.0156 \mathrm{x}}$ \\
\hline \multirow[t]{5}{*}{3.} & XS3 - LAI & - Logarithm & 0.8638 & $Y=4.354 \operatorname{Ln}(x)+57.432$ \\
\hline & & - Polynomial & 0.9180 & $\mathrm{Y}=-0.0001 \mathrm{x}^{2}+0.1181 \mathrm{x}+67.112$ \\
\hline & & - Linear & 0.9153 & $Y=0.0975 x+67.635$ \\
\hline & & - Power & 0.8919 & $\mathrm{Y}=58.86 \times 0.0596$ \\
\hline & & - Exponential & 0.9077 & $\mathrm{Y}=67.822 \mathrm{e} 0.0013 \mathrm{x}$ \\
\hline \multirow[t]{5}{*}{4.} & XS3 - Biomass & - Logarithm & $0 . .6970$ & $Y=15.131 \operatorname{Ln}(x)-29.539$ \\
\hline & & - Polynomial & 0.8701 & $Y=0.0005 x^{2}+0.2919 x+5.6771$ \\
\hline & & - Linear & 0.8677 & $\mathrm{Y}=0.3671 \mathrm{x}+3.7723$ \\
\hline & & - Power & 0.8758 & $Y=1.1506 \times 0.7662$ \\
\hline & & - Exponential & 0.7638 & $Y=7.8137 \mathrm{e} 0.0156 \mathrm{x}$ \\
\hline
\end{tabular}


height. This confirms the hypothesis that structural parameter is less important to support the study on spectral reflectance behavior of the vegetation. Therefore, measurement of the spectral reflectance values directly above the forest canopy is highly recommended to get a significant correlation between spectral reflectance of high resolution satellite data with the spectral reflectance obtained from field measurement and the vegetation parameters.

\section{Textural Analysis}

Textural analysis was done referring to spectral reflectance values which are randomly distributed on Landsat TM and SPOT data. Likewise, the vegetation parameters, especially LAI and biomass were calculated inside each parcel as imitating the pixel of Landsat TM and SPOT spatial resolution. Table 10 shows the value of entropy level as a measure of desegregation of parcels or pixels inside the 6 ha observation plot in the primary forest and logged-over forest.

Both in the Landsat TM and SPOT data, the entropy level of the logged-over forest is in general greater than those of the primary forest. It means that the perturbation occurring in the logged-over forest which appears in the form of mosaic of gaps (rigorousness or smoothness of the pixels/parcels) can be expressed by the value of "entropy level". The same aspect is equally found for LAI and biomass where the entropy values are greater in logged-over forest compared to those of the primary forest, indicating the heterogeneity level of the parcels analyzed. This is supported by the findings of Cohen and Spies (1992) where tree bole diameter, tree density, age and structural complexity index have contributed to the texture of the stand but were not significant for the tree height.

Table 10. Level of entropy of spectral reflectance values and vegetation parameters according to the pixel size of Landsat TM and SPOT

\begin{tabular}{|c|c|c|c|}
\hline Parciel'piziel & Parameters & Primiry; forest & Logged-over forest \\
\hline $\begin{array}{l}\text { I Andstat Th4 } \\
\text { usil } 30 \times 30 \text { m }\end{array}$ & $\begin{array}{ll}\text { I. } & \text { Hand TMZ } \\
\text { 2. } & \text { Bind TMS } \\
\text { 3. } & \text { Band ThM4 } \\
\text { 4. } & \text { LAT } \\
\text { 5. } & \text { BiLmass }\end{array}$ & $\begin{array}{l}\mathrm{H}^{\prime}=2.5994 \\
\mathrm{H}^{\prime}-2.4117 \\
\mathrm{H}^{\prime}-2.9764 \\
\mathrm{H}^{\prime}-2.6050 \\
\mathrm{H}^{\prime}=2.4221\end{array}$ & $\begin{array}{l}\mid \mathrm{H}^{\prime}=3.3614 \\
\mathrm{H}^{2}-2.496 \mathrm{~L} \\
\mathrm{H}^{3}=3.3 \mathrm{BT} \\
\mathrm{H}^{2}-2.862 \mathrm{~B} \\
\mathrm{H}^{3}=3.2558\end{array}$ \\
\hline $\begin{array}{l}\text { SPOT } \\
\text { unit } 20 \text { x } 20 \mathrm{ml}\end{array}$ & $\begin{array}{ll}\text { 1. } & \text { Band XSI } \\
\text { 2. } & \text { Bqud XS2 } \\
\text { 3. } & \text { Bind XS3 } \\
\text { 4. } & \text { LAJ } \\
\text { 5. } & \text { Ebonass }\end{array}$ & $\begin{array}{l}\mathrm{H}^{\prime}=2.0121 \\
1 \mathrm{I}^{\prime}=1.9546 \\
\mathrm{H}^{\prime}=5.4299 \\
\mathrm{H}^{\prime}=2.3210 \\
\mathrm{H}^{\prime}=2.3492\end{array}$ & $\begin{array}{l}H^{\prime}=1.9647 \\
H^{\prime}=2.0456 \\
H^{\prime}=4.0819 \\
H^{\prime}=3.8650 \\
H^{\prime}=3.7013\end{array}$ \\
\hline
\end{tabular}




\section{CONCLUSIONS}

Analysis of the spectral and textural patterns on Landsat TM and SPOT high resolution data to differentiate the logged-over forest from the primary forest mainly from the point of view of vegetation parameters and its response to radiation wavelength gave interesting results. From this study, it is obvious that the spectral reflectance alone cannot distinguish the logged-over forest from the primary forest; but in complement with the textural pattern analysis, it is possible to separate this logged-over forest from the primary forest. For the practical implementation of this findings, further study is needed to translate this formula into image classifier hi the image processing module.

\section{ACKNOWLEDGEMENT}

The authors would like to express their sincere gratitude to the peer-reviewers and to the Indonesian National Research Council for providing funds which made the conduct of this research possible from 1994 until 1996. Cordial appreciation is also addressed to the Barito Pacific Timber Group who has kindly provided facilities during the field work.

\section{REFERENCES}

COHEN, W.B. and T.A. SPIES. 1992. Estimating Structural Attributes of Douglas-fir Western Hemlock Forest Stands From Landsat and SPOT Imagery. Remote Sensing of Environment, 41(1): 1-17. FRANKLIN, S.E. and G.J. MCDERMID, 1993. Empirical Relation Between Digital SPOT HRV and CASI Spectral Response and Logepole Pine (Pinus concorta) Forest Stand Parameters. International Journal of Remote Sensing, 14(12): 2331-2348.

LAUMONIER, Y. 1992. The vegetation of Sumatera. SEAMEO BIOTROP Spec. Pub. Bogor.

OGAWA H., T. KIRA, K. YODA and K. OGINO, 1989. Comparative ecological studies on three main types of forest vegetation in Thailand. II. Plant Biomass. In: T. Kira and I. Iwata (eds). Nature and life in SEA. Fauna and Flora Res. Society, Kyoto, Japan.

TORQUEBIAU, E.F. 1988. Photosynthetically Active Radiation Environment, Patch Dynamics and Architecture in a Tropical Rainforest in Sumatera. Aust. J. Plant Physiol., 15.

TROTTER, C.M., J.R. DYMOND and C.J. GOTJLDING. 1997. Estimation of Timber Volume in a Coniferous Plantation Forest Using Landsat TM. International Journal of Remote Sensing, 18(10): 2209-2223. 